\title{
Community Structure and Distribution of the Ordo Anura in the Unmul Samarinda botanical Gardens (KRUS), Samarinda City, East Kalimantan
}

\author{
Lariman \\ Biology Department, Faculty of Mathematics and Natural Sciences, Mulawarman University \\ Jl. Barong Tongkok No.4 Kampus Gunung Kelua Samarinda, East Kalimantan
}

\begin{abstract}
Unmul Samarinda Botanical Gardens is a forest that grows naturally, along with population growth and the development of the city of Samarinda, the Unmul Samarinda Botanical Gardens (KRUS) is in the middle of the city. The Unmul Samarinda Botanical Garden is expected to function as an educational forest that supports science. Since 2001, Mulawarman University together with the Samarinda City government have developed a nature recreation/ecotourism function. In KRUS Forest, apart from high-level vegetation, shrubs, low-level vegetation and mosses are also found. Wild animals, birds, reptiles, amphibians and other aquatic animals also still exist in this area. This study aims to determine the diversity, evenness and dominance of the order anura. The method used in collecting data on the diversity of the Anura order is the Visual Encounter Survey (VES). For sample identification and data processing, it is carried out at the Laboratory of Animal Ecology and Systematics, Faculty of Mathematics and Natural Sciences, Mulawaman University, Samarinda. Research results show that the composition of the order Anura in the Unmul Samarinda Botanical Gardens (KRUS) consists of 18 species, 6 families and 108 individuals. Species with the highest number of individuals were Limnonectes paramacrodon and Pulchranapicturata. The index of species diversity of the order Anura is moderate with a value of 2.26, the index of evenness is relatively even with a value of 0.79 and the dominance index indicates that there is no dominant species with a value of 0.17 . There are several factors that pose a threat to the species of the Anura order in the Educational forest of the Unmul Samarinda Botanical Gardens (KRUS), such as tourism activities and coal mining which makes the forest fragmented.
\end{abstract}

Keywords: Diversity, Evenness, Dominance, Order of Anura, Educational Forest

\section{INTRODUCTION}

$\mathrm{S}$ amarinda City is one of the cities in East Kalimantan province which has high biological potential. This is supported by the geographical position of the city of Samarinda which is close to the equator in which there is a tropical rain forest that is rich in biological potential, both flora and fauna. It is not surprising that some areas in the city of Samarinda can be found natural attractions. One of them is the Unmul Samarinda Botanical Garden (KRUS) located in Lempake, North Samarinda District. As it is known that the Forest in the Botanical Gardens is a natural forest located in the Tropical Rain Forest zone which is still rich in various types of flora and fauna. In fact, many studies have been carried out in the Botanical Gardens area by students, local and foreign researchers, but because they are not well coordinated, the data is difficult to access.

The Unmul Samarinda Botanical Garden is expected to function as an educational forest that supports science. Since 2001, Mulawarman University together with the Samarinda City government have developed this function towards natural recreation. With the community gathering every day at the Unmul Samarinda Botanical Gardens, it is only natural thatThis place is used as an information center, because with recreation visitors can enrich themselves with valuable information.

As an illustration, previously the Botanical Gardens area experienced several forest fires, namely in 1982/1983, $1992 / 1993$, and 1997/1998. The 1982/1983 fires were quite extensive, resulting in a degradation of vegetation conditions. Before the fire there were 209 tree species, 125 families, and 445 individual trees per hectare. On the other hand, after a forest fire, the number of tree species was 199, the number of families was 113 and the number of individual trees was 335, per hectare with diameter $>10 \mathrm{~cm}$. (Riswan and Yusuf, 1984).

In the 1999 inventory after the 1997/1998 fires, in the old secondary forest stands that were not completely burned, it was found that there were 650 surviving trees $>10 \mathrm{~cm}$ in diameter from 116 tree species. HPHI's latest inventory of 150 ha contains 2600 individual live trees $>50 \mathrm{~cm}$ in diameter. But many have been disabled. Therefore, it is important to maintain, improve the quality and quantity of biological and vegetable natural diversity in conserving flora and fauna natural resources in the UnmulSamrinda Botanical Gardens. We absolutely maintain this as an invaluable asset in life and science.

Unmul Samarinda Botanical Gardens is a forest that grows naturally, along with population growth and the development of the city of Samarinda, Unmul Samarinda Botanical Gardens are in the middle of the city. Here you can still find large tree species that were once the prima donna of Indonesian wood exports abroad and a fairly large foreign exchange earner. In addition to high-level vegetation, thickets are also found in many low-level vegetation and mosses. Wild 
animals, birds, reptiles, amphibians and other aquatic animals are also still present in this Botanical Gardens area.

Amphibians are literally defined as animals that go through two phases of life, namely the tadpole phase living in water and the adult phase living on land, while the reproductive period returns to water again. Amphibians are known as vertebrate animals whose body temperature depends on the environment, has smooth and glandular skin and does not have scales. Most have limbs with fingers. Amphibians are divided into 3 (three) orders, namely Urodela (salamander), Gymnophiona (cecilia) and Anura (frogs and toads) (Mistar, 2008).

In natural ecosystems, amphibians have an important role in maintaining environmental balance and have a fairly high ecological value. Amphibians are a group of animals that are very sensitive to environmental changes such as water pollution, destruction of natural habitats, the introduction of exotic species, diseases and parasites (Kusrini, 2009). According to Mistar (2008), the conversion of land from forest to agricultural, plantation and residential areas can threaten the existence of amphibians. Environmental conditions and land use change greatly affect the composition and distribution of amphibians. According to Putra's research (2012), the structure of the amphibian community and its distribution pattern is highly dependent on environmental characteristics and the biological nature of the organism itself.

Amphibian species in Indonesia based on information from the IUCN (International Union for Conservation of Nature and Natural Resources) data in 2008 recorded 39 species that have been included in the red list category. Meanwhile, research on amphibians in Kalimantan has so far not been thoroughly explored, even though the types of amphibians in Kalimantan, especially the order Anura, have high species diversity and some of them are endemic species (Eprilurahman, 2012). Abdiansyah (2011), in the protected forest area of the Lesan River, East Kalimantan found as many as 31 types of amphibians and 12 of them are endemic species.

Until now, research and publications on the community structure and distribution of amphibians, especially the Anura order in the Unmul Samarinda Botanical Gardens area, East Kalimantan have never been carried out, even though information on the diversity, wealth, status and distribution of amphibian species is very important as a bioindicator for management efforts in the area and additional scientific information about the existence of amphibian species in East Kalimantan.

\section{METHODOLOGY}

The research survey was conducted at the Unmul Samarinda Botanical Gardens (KRUS), Samarinda City, East Kalimantan. Research activities were carried out from February to April 2020 for sampling and analysis in the laboratory. The sampling station was determined based on the characteristics of the amphibian habitat type in small rivers and swamps. Amphibian observations were carried out using the Purposive Sampling method combined with the Visual Encounter Survey (VES) search method by directly searching for amphibian species in the vicinity of a predetermined station.
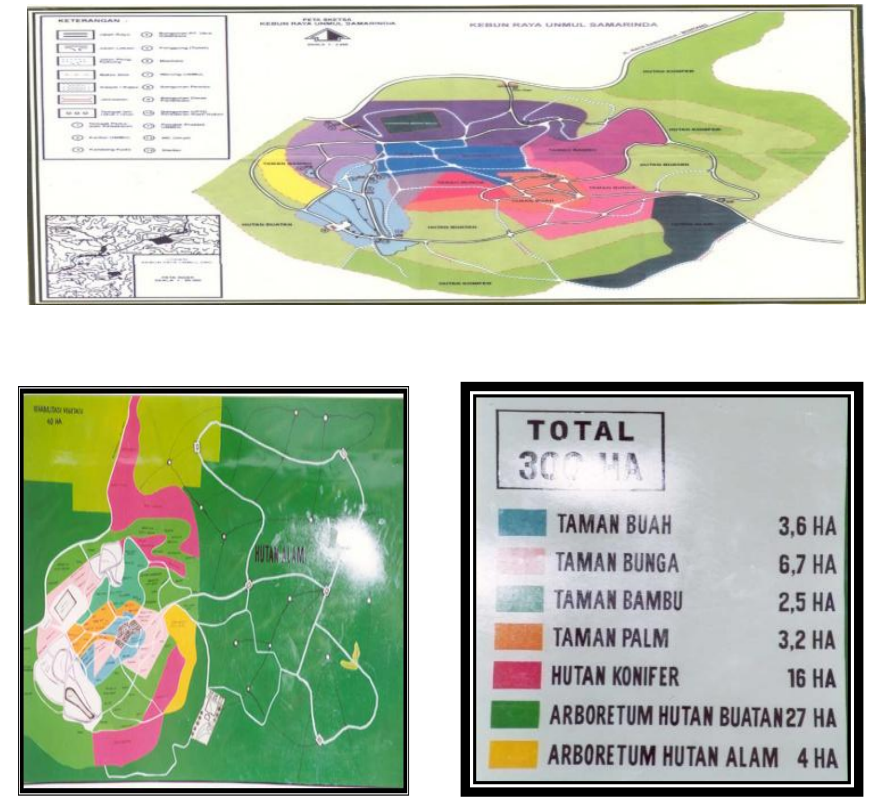

Figure 1: Sketch Map of Unmul Samarinda Botanical Gardens

The method used in collecting data on the diversity of the order Anura is the Visual Encounter Survey (VES) (Heyeret al. 1994). The technique of implementing the method in the field is carried out with the following procedure:

a. Field and exploration orientation.

b. Making an observation path at each location, which is $500 \mathrm{~m}$ for aquatic habitats (lebung), by following the flow of the water.

c. Catching and collecting samples was done by visiting the observation lines in the morning and evening for 3 replications for each line. Each individual of the Anura order caught and recorded when found, activity/behavior, horizontal and vertical position, subtract type and other information (Heyer et al. 1994) was then marked to be released again.

d. Identification activities were carried out using the books of Iskandar (1998) and Darmawan (2008).

Sample identification and data processing were carried out at the Laboratory of Animal Ecology and Systematics, Faculty of Mathematics and Natural Sciences, Mulawaman University, Samarinda.

\subsection{Tools and materials}

\subsubsection{The tools used in this research are:}

Meter $(50 \mathrm{~m})$, machete and GPS, headlamp, flashlight, net, specimen bag, permanent marker, watch/stopwatch, stationery, calipers, data sheet, scale $(0.1 \mathrm{~g}-1 \mathrm{~kg})$, sample 
tube, syringe and loops, thermometers, hygrometers and $\mathrm{pH}$ meters.

2.1.2. The materials used in this research are:

Formalin, 70\% alcohol, cotton, label paper and yarn.

\subsubsection{Data analysis}

\subsubsection{Diversity}

To determine the diversity of species used Shannon Wiener Index (Brower and Zar 1997).

$S$

$\mathrm{H}^{\prime}=-\sum P i \ln P i$

$i=1$

Information:

$\mathrm{H}^{\prime}=$ Shannon-Weaver Diversity Index.

$\mathrm{Pi}=$ The proportion of the number of species to $-\mathrm{I}$ of the number of individuals of all species.

$n i=$ Number of individuals of the $\mathrm{i}$-th type .

$\mathrm{N}=$ Total number of individuals of all species.

$\mathrm{s}=$ Number of types.

According to (Odum, 1993) the criteria for diversity index if $\mathrm{H}^{\prime}<1$, then diversity is low, $\mathrm{H}^{\prime} 1-3$, then diversity is moderate, and $\mathrm{H}^{\prime}>3$, then diversity is high.

\subsubsection{Evenness of type (Evenness)}

Evenness is calculated to determine the even distribution of individuals of a species in the community (Bower and Zar 1997). Evenness is calculated using the following formula:

$\mathrm{H}^{\prime} \mathrm{E}=$

\section{$\ln S$}

Information:

$\mathrm{E}=$ Specific evenness index

$\mathrm{H}^{\prime}=$ Shannon-Wiener diversity index

$\mathrm{S}=$ Number of species found

The range of evenness values is between 0 to 1 , if the value of $\mathrm{E}<0.4$ is low evenness, $\mathrm{E}$ is $0.4-0.6$ is medium evenness and $\mathrm{E}$ is $0.6-1$ is high evenness (Fachrul, 2007).

\subsubsection{Dominance Index (Simpson).}

To calculate the dominance is done by using the formula:

$\mathrm{S}$

$\mathrm{C}=\sum(P i) 2$

$\mathrm{i}=1$

Information:
$\mathrm{C}=$ Dominance Index .

$\mathrm{Pi}=$ The proportion of the number of species to $-\mathrm{I}$ of the number of individuals of all species.

$\mathrm{ni}=$ Number of individuals of the i-th type.

$\mathrm{N}=$ Total number of individuals of all species. $\mathrm{S}=$ Number of types.

According to (Fachrul, 2007). the range of dominance index is between $0-1$, if the value is closer to 1 , it means that the dominance by certain species is also higher.

\section{RESULTS AND DISCUSSION}

\subsection{Environmental conditions}

Species of the order Anura are poikilothermic vertebrates that are very dependent on the surrounding environmental conditions such as air temperature, humidity, water temperature, water $\mathrm{pH}$ and current speed. The results of measurements of air temperature and humidity at the study site ranged from $25-29^{\circ} \mathrm{C}$ and $88-96 \%$ respectively, while measurements in the body of water obtained water temperature $23-28^{\circ} \mathrm{C}$, and water $\mathrm{pH} 6.89-7.47$ as shown in Table 3.1.

Table 3.1: The value of the range of environmental parameters in the Unmul Botanical Gardens area

\begin{tabular}{|c|c|l|c|c|c|}
\hline No & Habitat & \multicolumn{4}{|l|}{ Temperature $\left({ }^{\circ} \mathrm{C}\right)$} \\
\hline & & WaterAir & $\begin{array}{c}\text { Humidity } \\
(\%)\end{array}$ & $\begin{array}{c}\text { Water } \\
\mathrm{pH}\end{array}$ & Diversity \\
\hline 1 & Swamp & $\begin{array}{l}22-26 \\
24-29\end{array}$ & $88-96$ & $\begin{array}{l}6,78- \\
7,60\end{array}$ & 2,21 \\
\hline 2 & Bush & $\begin{array}{l}21-26 \\
24-29\end{array}$ & $88-97$ & $\begin{array}{l}6,89- \\
7,77\end{array}$ & 2,16 \\
\hline 3 & Forest & $\begin{array}{l}21-25 \\
24-27\end{array}$ & $90-98$ & $\begin{array}{l}7,05- \\
7,78\end{array}$ & 2,18 \\
\hline
\end{tabular}

Environmental conditions during the study in terms of air temperature, water temperature and humidity at the research site showed ideal values for amphibian life in general. The air temperature obtained at the research location during observations ranged from $25^{\circ} \mathrm{C}-29^{\circ} \mathrm{C}$, while the water temperature was in the range of $21^{\circ} \mathrm{C}-26^{\circ} \mathrm{C}$. According to (Wells, 2007) stated that amphibians get the optimum growth temperature between $26^{\circ} \mathrm{C}-33^{\circ} \mathrm{C}$.

The results of the measurement of air humidity at the research site ranged from $88 \%-96 \%$, the humidity in each research habitat was still able to support amphibian life. According to Novitasari (2014), the humidity in the forest is relatively higher, this is due to the presence of tree canopy closures that block sunlight and wind. According to Iskandar (1998), amphibians need sufficient moisture to protect themselves from drying out their skin.

Amphibians need water to lay eggs and develop. The water temperature obtained at the research location ranged from $21^{\circ} \mathrm{C}-26^{\circ} \mathrm{C}$, indicating that the water temperature is capable of supporting amphibian life, especially anura. The degree of 
acidity or $\mathrm{pH}$ of the water obtained in the aquatic pathway in all research habitats ranged from 6.78 to 7.78 . According to (Wells, 2007) it was stated that the anura larvae of the bufo group (frogs) tended to live at an average water temperature of $30^{\circ} \mathrm{C}$, while the shutter group (frogs) tended to live at an average water temperature of $24^{\circ} \mathrm{C}$. According to Nasaruddin (2008) the optimal range of $\mathrm{pH}$ for amphibians in general is between $6.5-8.5$.

\subsection{Structure and composition of species of the order Anura}

The species of the order Anura that were found in all research locations in various habitat

types in the Unmul Samarinda Botanical Gardens, East Kalimantan belong to 6 families, the family Bufonidae (3 species), family Megophryidae (1 species), family Ranidae (5 species) and family Microylidae (1 species), familia Dicroglossidae (6 species), and familia Rhacophoridae (2 species) complete data can be seen in Table 3.2.

Table 3.2. The structure and composition of the order Anura in each habitat in the Unmul Samarinda Botanical Gardens

\begin{tabular}{|c|c|c|c|c|c|}
\hline $\begin{array}{l}\text { Familia } \\
\text { Spesies }\end{array}$ & Habitat Type & & & & Total \\
\hline & & Swamp & Bush & Forest & \\
\hline \multirow[t]{3}{*}{ Bufonidae } & $\begin{array}{c}\text { Ansoniaspinulif } \\
\text { er }\end{array}$ & - & - & $\mathrm{v}$ & 4 \\
\hline & $\begin{array}{c}\text { Duttaphrynusm } \\
\text { elanostictus }\end{array}$ & $\mathrm{v}$ & $\mathrm{v}$ & $\mathrm{v}$ & 7 \\
\hline & $\begin{array}{c}\text { Ingerophrynus } \\
\text { divergens }\end{array}$ & $\mathrm{v}$ & $\mathrm{v}$ & $\mathrm{v}$ & 6 \\
\hline \multirow[t]{6}{*}{$\begin{array}{c}\text { Dicroglossid } \\
\mathrm{ae} \\
\end{array}$} & $\begin{array}{l}\text { Fejervarya } \\
\text { limnocharis }\end{array}$ & $\mathrm{v}$ & $\mathrm{v}$ & $\mathrm{v}$ & 3 \\
\hline & $\begin{array}{c}\text { Limnonecteslep } \\
\text { orinus }\end{array}$ & $\mathrm{v}$ & $\mathrm{v}$ & $\mathrm{v}$ & 5 \\
\hline & $\begin{array}{c}\text { Limnonectespa } \\
\text { ramacrodon }\end{array}$ & $\mathrm{v}$ & $\mathrm{v}$ & $\mathrm{v}$ & 28 \\
\hline & $\begin{array}{c}\text { Limnonectesku } \\
\text { hlii }\end{array}$ & $\mathrm{v}$ & $\mathrm{v}$ & $\mathrm{v}$ & 8 \\
\hline & $\begin{array}{c}\text { Limnonectesfin } \\
\text { chi } \\
\end{array}$ & $\begin{array}{ll}- & -1 \\
-1\end{array}$ & $\mathrm{v}$ & $\mathrm{v}$ & 2 \\
\hline & $\begin{array}{c}\text { Limnonectesiba } \\
\text { norum }\end{array}$ & $\mathrm{v}$ & $\mathrm{v}$ & $\mathrm{v}$ & 4 \\
\hline $\begin{array}{c}\text { Megophryida } \\
\text { e } \\
\end{array}$ & $\begin{array}{c}\text { Leptolalaxgraci } \\
\text { lis } \\
\end{array}$ & v & $\mathrm{v}$ & $\mathrm{v}$ & 4 \\
\hline Microhylidae & $\begin{array}{l}\text { Microhyla } \\
\text { berdmorei }\end{array}$ & $\mathrm{v}$ & - & - & 1 \\
\hline \multirow[t]{5}{*}{ Ranidae } & $\begin{array}{c}\text { Amnirananicob } \\
\text { ariensis }\end{array}$ & $\mathrm{v}$ & $\mathrm{v}$ & - & 3 \\
\hline & $\begin{array}{c}\text { Chalcoranacha } \\
\text { lconota }\end{array}$ & $\mathrm{v}$ & - & - & 1 \\
\hline & $\begin{array}{c}\text { Chalcoranaran } \\
\text { iceps }\end{array}$ & - & - & $\mathrm{v}$ & 1 \\
\hline & Odorranahosii & $\mathrm{v}$ & - & - & 1 \\
\hline & $\begin{array}{c}\text { Pulchrana } \\
\text { picturata }\end{array}$ & $\mathrm{v}$ & $\mathrm{v}$ & $\mathrm{v}$ & 26 \\
\hline
\end{tabular}

\begin{tabular}{|c|c|c|c|c|c|}
\hline $\begin{array}{c}\text { Rhacophorid } \\
\text { ae }\end{array}$ & $\begin{array}{c}\text { Polypedatesleu } \\
\text { comystax }\end{array}$ & - & $\mathrm{v}$ & $\mathrm{v}$ & 2 \\
\hline & $\begin{array}{c}\text { Polypedatesotil } \\
\text { ophus }\end{array}$ & $\mathrm{v}$ & - & - & 1 \\
\hline
\end{tabular}

Based on Table 3.2. Most of the species of the order Anura found were from the Dicroglossidae family as many as 6 species and followed by the Ranidae family as many as 5 species, while the Microhylidae and Megophryidae families only found one species. Species with a dominant number of individuals were found at the four stations, namely Limnonectesparamacrodon as many as 28 individuals and Pulchranapicturata as many as 26 individuals, while the species Chalcoranachalconota, Chalcoranaraniceps, Odorranahosii and Polypedatesotilophus were only found in one individual.

The number of species of the order Anura found during the study was 18 species, the same as the research conducted by Aditya (2018) at the Berambai Waterfall Nature Tourism Object, Samarinda, East Kalimantan, while another study conducted in West Kalimantan by Novitasari (2014) in the Gunung Protection Forest Ambawang found 11 species of amphibians, while Yani (2015) in the Mount Semahung Protection Forest as many as 18 species, in East Kalimantan, Abdiansyah (2011) conducted research in the Lesan River Protection Forest found 31 species of amphibians. The difference in the number of species found is thought to be caused mainly by differences in habitat conditions and geographical areas, but it can also be caused by differences in efforts to searchamphibians and area. According to Inger and Vorris (1993) stated that differences in topography, vegetation, rainfall or physical characteristics of rivers will affect variations in the discovery of amphibian species in an area. According to Kusrini (2007) effort will affect the results of the amphibian survey based on the length of the search, the number of researchers in the field, and the area surveyed.

Based on the composition of the order Anura, the most commonly found were from the family Dicroglossidae, which consisted of two genera, namely Fejervarya and Limnonectes. There were 5 species of Limnonectes genus, namely $\mathrm{L}$. leporinus, L. paramacrodon, L. kuhlii, L. finchi and L. ibanorum. The genus Limnonectesis generally found on riverbanks and also on riverbanks at the study site. According to Iskandar (1998), species belonging to the genus Limnonectes are always associated with rivers that flow slowly or quietly and are not too deep.

In the family microhylidae and megophryidae the number of species found was 1 species, namely Microhylaberdmorei and Leptolalaxgracilis, respectively. Species from the family Microhylidae are difficult to find because of the relatively smaller body size of this family. According to Iskandar (1998), the genus Microhyla is often invisible because of its relatively small body size of no more than $25 \mathrm{~mm}$, so it looks like a young frog from a larger frog, while species from the 
Megophryidae family are also very difficult to find because they are litter frogs that are capable of camouflaging. among the litter on the forest floor.

\subsection{Diversity, Evenness and Dominance of Species of the order Anura}

The results of the calculation of the diversity index, evenness index and dominance index of members of the Anura order (Table 3.3) obtained a diversity index of 2.26 , an evenness index of 0.79 and a dominance index of 0.17 .

Table 3.3 Comparison of diversity, evenness and dominance of ordo Anura species in each habitat

\begin{tabular}{|c|c|c|c|c|c|}
\hline & \multicolumn{5}{|c|}{ Habitat } \\
\hline No Parameter & Swamp & Bush & $\begin{array}{c}\text { For } \\
\text { est }\end{array}$ & Total & $(\mathrm{N})$ \\
\hline $\begin{array}{c}\text { 1Number } \\
\text { ofSpecies }\end{array}$ & 14 & 12 & 13 & 18 & \\
\hline $\begin{array}{c}\text { 2Number } \\
\text { ofindividuals }\end{array}$ & 38 & 35 & 35 & 108 & \\
\hline $\begin{array}{c}\text { 3 Diversity } \\
\text { Index(H) }\end{array}$ & 2,21 & 2,16 & $\begin{array}{c}2,1 \\
8\end{array}$ & 2,26 & \\
\hline $\begin{array}{c}\text { 4Evenness Index } \\
\text { (E) }\end{array}$ & 0,89 & 0,75 & $\begin{array}{c}0,9 \\
4\end{array}$ & 0,79 & \\
\hline $\begin{array}{c}\text { 5Dominance } \\
\text { Index(C) }\end{array}$ & 0,15 & 0,30 & $\begin{array}{c}0,1 \\
3\end{array}$ & 0,17 & \\
\hline
\end{tabular}

\section{Description: $\mathrm{N}=$ Total}

The diversity index, evenness index and dominance index of amphibian species in each habitat were not much different and the overall diversity index was in the moderate category, but if viewed from the values in swamp and forest habitats, the diversity index was slightly higher than that of bush habitats. . The same value is also seen in the evenness index that swamp and forest habitats are more evenly distributed than bush habitats, while the dominance index which indicates swamp and forest habitats is lower than bush habitats.

Based on the composition of amphibians, the most common families found were from the family Dicroglossidae which consisted of two genera, namely Fejervarya and Limnonectes. There were 5 species of Limnonectes genus, namely $\mathrm{L}$. leporinus, L. paramacrodon, L. kuhlii, L. finchi and L. ibanorum. The genus Limnonectes is generally found on riverbanks and also on riverbanks at the study site. According to Iskandar (1998), species belonging to the genus Limnonectes are always associated with rivers that flow slowly or quietly and are not too deep.

In the family microhylidae and megophryidae the number of species found was 1 species, namely Microhylaberdmorei and Leptolalaxgracilis, respectively. Species from the family Microhylidae are difficult to find because of the relatively smaller body size of this family. According to Iskandar (1998), the genus Microhyla is often invisible because of its relatively small body size of no more than $25 \mathrm{~mm}$, so it looks like a young frog from a larger frog, while species from the Megophryidae family are also very difficult to find because they are litter frogs that are capable of camouflaging. among the litter on the forest floor.

The Unmul Samarinda Botanical Garden Forest (KRUS) shows a fairly good carrying capacity as indicated by an amphibian diversity index of $\mathrm{H}^{\prime}=2.26$, an evenness index of $\mathrm{E}=0.79$ and a dominance index of $\mathrm{C}=0.17$. The diversity index shows that the diversity of amphibian species is included in the moderate criteria. According to Odum (1993) the diversity index is classified with moderate criteria if the value is between a value range of $1-3$, which indicates that forest vegetation and the surrounding environment have sufficient carrying capacity for the life of the Anura order as their habitat (Rahardian, 2015).

There are several factors that pose a threat to the species of the Anura order in the Educational forest of the Unmul Samarinda Botanical Gardens (KRUS), such as the existence of a tourist area that makes the forest fragmented. Coal mining around the area also affects the condition of the river which is the habitat of several species of the Anura order. According to the IUCN report (2017), the cause of the threat and decline in amphibian populations is the deforestation of most habitats such as forest clearing into plantation and mining areas, forest fires and also river pollution and the loss of natural springs in the forest. In addition, amphibians that are able to grow large, such as L. leporinus and L. paramacrodon species are often hunted by local people for consumption and the age of the adult stage of gonad maturity is long.

\section{CONCLUSION}

Based on the research on community structure and distribution of the Anura order that has been carried out at the Unmul Samarinda Botanical Gardens (KRUS), the following conclusions can be drawn:

1. The composition of the order Anura in the Botanical Gardens Unmul Samarinda (KRUS) consists of 18 species, 6 families and 108 individuals. Species with the highest number of individuals were Limnonectesparamacrodon and Pulchranapicturata.

2. The Unmul Samarinda Botanical Garden Forest (KRUS) shows a moderate species diversity index of the Anura order with a value of 2.26 , a relatively evenness index with a value of 0.79 and a dominance index showing no dominant species with a value of 0.17 .

3. There are several factors that pose a threat to the species of the Anura order in the Educational forest of the Unmul Samarinda Botanical Gardens (KRUS), such as tourism activities and coal mining which makes the forest fragmented.

\section{SUGGESTION}

It is necessary to carry out further research on the diversity of amphibians of the order Anura in the same habitat type in other Educational forests in East Kalimantan, in order to compare the diversity related to the specific conditions of each 
habitat.

\section{REFERENCE}

[1] Ardiyansyah, D. and Priyono, A. Amphibian and Reptile Conservation in Indonesia. Proceedings. Seminar on research results from the Department of Forest Resources Conservation. Bogor. 181 pages.

[2] Alikodra, H.S. 2010. Wildlife Management Techniques. Bogor: IPB Press.

[3] [IUCN] International Union for Conservation of Nature and Natural Resources, Conservation International, and Nature Serve. $2008 . \quad$ Major Threats. http://www.iucnredlist.org/amphibians/major_threats.htm.

[4] [IUCN] International Union for Conservation of Nature and Natural Resources, Conservation International, and Nature Serve. $2017 . \quad$ Major Threats. http://www.iucnredlist.org/amphibians/major_threats.htm.

[5] Brower, J. E., and Zar, J. H. 1977. Field and Laboratory Methods for General Ecology. Book. Brown Co Publisher, Iowa. USA

[6] Darmawan, B. 2008. Amphibian Diversity in Various Habitat Types: A Case Study in Ex-HPH PT Rimba Karya Indah Bungo Regency, Jambi Province. Essay. Bogor Agricultural Institute. Bogor. 78 pages.

[7] Duellman, W. E., and Trueb, L. 1994. Biology of Amphibians. Book. Johns Hopkins Univ. Pr. London.

[8] Goin, C. J., Goin, O. B., and Zug, G. R. 1978. Introduction to Herpetology. Book. W.H Freeman and Company. San Francisco. 378 pages.
[9] Heyer, W. R., Donnelly, M. A., Diarmid, M. C., Hayek, L. C., and Foster MS. 1994. Measuring and Monitoring Biological Diversity: Standard Methods for Amphibians. Washington: Smithsonian Institution Press.

[10] Inger, R. F., and Iskandar, D. T. 2005. A collection of amphibians from West Sumatra, with a description of a new species of Megophrys (Amphibia: Anura). The Raffles Bulletin of Zoology. 53(1): 133-142.

[11] Inger, R. F., and Stuebing, R. B. 1997. A Field guide to the Frogs of Borneo. Book. Natural History Publications. Sabah. 205 pages.

[12] Iskandar, D. T. 1998. Java and Bali Amphibians-Field Guide Series. Research and Development Center for Indonesian Research Institute of Sciences. Bogor. ruler. 2003. Amphibious Field Guide for the Leuser Ecosystem. Book. The Gibbon Foundation and the PILI-NGO Movement. Bogor.

[13] Odum, E. P. 1971. Fundamentals of Ecology. Book. Saunders. Philadelphia.

[14] Putra, K., Rizaldi. Djong Hon Tjong. 2012. Anura (Amphibia) Community in Three Types of Aquatic Habitats in Harapan Forest Area, Jambi. Andalas University Biology Journal. 1(2): 156-165.

[15] Pratomo, H. 1994. Diversity and Ecology of the Genus Rana (Amphibia: Ranidae) in Bogor, Sukabumi and Cianjur areas. Postgraduate Thesis. Bogor Agricultural Institute. Bogor.

[16] Stebbins, R. C., and Cohen, N. W. 1997. A Natural History of Amphibians. Book. Princeton Univ. New Jersey.

[17] Solahudin AM. 2003. Diversity of waterbird species in LebakPampangn, Pampangan District, OganKomeringIlir Regency, South Sumatra. Essay. University of Lampung. Bandar Lampung 